Jurnal Ar-Rihlah Inovasi Pengembangan Pendidikan Islam

Volume. 5. No.1. 2020 Fakultas Tarbiyah IAINU Kebumen

ISSN: $2541-402 X$

ISSN: 2851-0197

http://ejournal.iainu-kebumen.ac.id/index.php/Ar-rihlah/index

\title{
Tradisi Pengajian Lapanan Dalam Atifitas Sosial Masyarakat
} (Studi Desa Kedungwinangun Kecamatan Klirong, Kebumen

\author{
Bahrun Ali Murtopo \\ Agus Salim Chamidi \\ (Instutut Agama Islam Nahdlatul Ulama Kebumen) \\ bahrunalimurtopo@gmail.com
}

\begin{abstract}
Abstrak
Pengajian lapanan dalam Nilai-nilai Keagamaa. Munculya Pengajian lapanan dewasa ini merupakan fenomena menarik. Pengajian lapanan lahir bersamaan dengan kompleksitas persoalan yang dihadapi di masyarakat, seperti pencurian, narkoba, pergaulan bebas dan lain sebagainya. Oleh karena itu, bermula dari kesadaran masyarakat untuk membendung persoalan tersebut melalui pemahaman dan peningkatan nilai-nilai agama mutlak dilakukan. Pengajian lapanan tidak sekedar sebagai aktivitas keagamaan yang lebih mengutamakan aspek ritualistik, lebih jauh Pengajian lapanan membenahi diri sebagai proses pendidikan, yang mengajarkan dan berperan menanamkan nilai-nilai keagamaan pada masyarakat sebagai tambahan sepiritual relijius. Aqidah tentang keimanan yang mencakup rukun Iman yang lima, akhlak atau perilaku seperti mengucapkan salam ketika bertamu dan menghormati orang. dalam menanamkan nilai-nilai keagamaan bagi masyarakat adalah berperan sebagai kreator (yang pertama memulai atau mengawali), fasilitator (yang menyediakan), dan edukator (pendidikan). membuat kegiatan pengajian lapanan pada masyarakat dan remaja agar remaja di desa lebih aktif pada kegiatan keagamaan, sosial dan budaya yang baik untuk menambah atau memaksimalkan Peranan masyarakat dalam kehidupan sosila masyarakat.
\end{abstract}

Kyawod: Tradisi Lapanan, Aktifitas Sosisal, Masyarakat 
Jurnal Ar-Rihlah Inovasi Pengembangan Pendidikan Islam

Volume. 5. No.1. 2020 Fakultas Tarbiyah IAINU Kebumen

ISSN: $2541-402 X$

ISSN: 2851-0197

http://ejournal.iainu-kebumen.ac.id/index.php/Ar-rihlah/index

\section{A. PENDAhULUAN}

Pengajian lapanan merupakan satu ibadah tambahan sebagai jalan untuk mendekatkan diri kepda sang pencipatanya dengan cara melukan kegiatan yang sudah tercatum dengan hitungan tiga puluh lima hari sekali, pengajian lapanan dengan di pipim seorang kiai.

Pengajian lapanan adalah ibdah tambahan yang merupakan amilah yang di lakukan seseorng setelah melukan kewajiban ibadah wajib, ibadah yang di maksud dalam Pengajian Lapanan disini ibadah tidak memangung kewajiban sebagai hamba Allah SWT yaitu menjahi perintah dan menjauhi laranganya. Pengajian lapanan di sajikan bagi orang-orang yang ingin berkumpul dan mau mencari ilmu.

Tempat lembaga mengaji dan mendalamim agama islam, di indonesia banyak bentuk wadah pengajian dimsyakat di masing-masing daerah masyarkat muslim. Akan tetapi belakangankan ini, fenomena yang menarik untuk diamati adalah terjadinya berbagai perubahan yang begitu pesat. Perubahan itu menimbulkan kesadaran baru di masyarakat tentang masalah nilai dan penghayatan terhadap pemahaman, dan kesadaran religi (transenden) dimana perlunya peninjauan dan penataan kembali nilai-nilai (rearrangement), baik tata nilai budaya yang berskala lokal, regional, nasional, maupun internasional.

Dalam kehidupan sosial dewasa terjadi perubahan sangat drastis berbagai sektor, bahwa perubahan tersebut meliputi ekonomi, sosial, budaya sampai pada kesadaran untuk beragaman dan juga perubahan pada moral. Pada saat sekarang ini banyak terjadi fenomena perubahan sosial dalam masyarakat khususnya dalam prilaku yang mengalami penurunan moral yang mengakibatkan menurunya nilai etika dan tata krama dalam masyarakat.

Hal ini disebabkan pula karena begitu cepat informasinya kemasyarakat, kemampuan selektif dan adaptasi dengan hilangnya nilai tradisi sebagai pengikat kehidupan bersama mulai melonggar, sehingga terjadi banyak penyimpangan sosial. Salah satu dampaknya ialah meningkatnya, kurang sopan satun pada orang tua, enggo sentris, kriminalitas, bahkan ada yang mengatakan bahwa masyarakat moderen telah 
Jurnal Ar-Rihlah Inovasi Pengembangan Pendidikan Islam

Volume. 5. No.1. 2020 Fakultas Tarbiyah IAINU Kebumen

ISSN: $2541-402 X$

ISSN: 2851-0197

http://ejournal.iainu-kebumen.ac.id/index.php/Ar-rihlah/index

menderita penyakit kleptokrasi. Bentuk-bentuk kleptokrasi ini misalnya terlihat di dalam semakin meningkat gejala-gejala korupsi ${ }^{1}$.

Pengajian lapanan Desa Kedungwinagun merupakan salah satu ibadah tambahan sebagai mendekatkan diri kepada sang pencipta-Nya dengan cara melakukan kegiatan yang sudah tercantum pengajian lapangan yang sudah terpimpin oleh seorang kyai.

Pengajian lapanan ini merupakan tradisi islami. Tradisi ini bisa hilang apabila tatanan kehidupan pada tingkat makro sudah termasuki dari dampak globlalisasi, salah satu dari unguri-uri tradisi ini adalah mengaktualisasikan nilai-islami dalam kehidupan sosial.

Pemahaman di atas tidak sesuai dengan pengajian lapanan sebagai salah satu jalan untuk mendekatkan diri kepada Allah dengan sunguh-sunguh dan iklas dalam beribadah serta tidak berperasangka buruk akan apa yang mereka alami jika tidak sesuai yang diinginkan. Salah satu dari usaha tersebut adalah dengan adanya pengajian lapanan yang berusaha untuk menampung jama'ah pengajian yang ada, dengan tujuan untuk menjadikan jam'ah pengajian dalam hal ini sebagai murid lebih arif dan bijaksana dalam menjalankan kehidupan sebagi hamba Allah.

Dari Judul. "Tradisi Pengajian Lapanan Dalam Atifitas Sosial Masyarakat (Studi Desa Kedungwinangun Kecamatan Klirong, Kebumen)". Penelitian mengunakan Teori Sruktural fungsi sosial struktural ${ }^{2}$ bertujuan untuk mengetahui dan memahami perilaku sosial keagamaan Pengajian lapanan, terhadap peran sosial di masyarakat. Penelitian ini memberikan solusi alternatif bagi masyarakat atau pengajian sejenis dalam kontribusinya membangun masyarakat yang berkemajuan dan menuju Islam Rahmatan Lil 'Alamin.

1. Rumusan Maslah

\footnotetext{
${ }^{1}$ H.A.R Tilaar, PerubahanSosial Dan PendidikanPengantarPedogogikTransformatifUntuk Indonesia, ( jakarta: PT Gransindo. 2002, hlm 65)

${ }^{2}$ Wahyuni, Agama dan Pembentukan Struktur Sosial: Pertautan Agama, Budaya, dan Tradisi Sosila, (Perpustakaan Nasional, dalam terbitan KDT, tahun 2018)
} 
Jurnal Ar-Rihlah Inovasi Pengembangan Pendidikan Islam

Volume. 5. No.1. 2020 Fakultas Tarbiyah IAINU Kebumen

ISSN: $2541-402 X$

ISSN: 2851-0197

http://ejournal.iainu-kebumen.ac.id/index.php/Ar-rihlah/index

a. Bagaimana atifitas Pengajian Lapanan dalam pendidikan islam dimaknai oleh masyarakat kedungwinangun?

b. Bagaimana peran/kontribusi Pengajian Lapanan terhadap Sosial masyarakat kedungwinangun?

\section{B. Kajian Dan Krangka Teori}

Pengajian secara umum merupakan sebuah tradisi keagamaan yang biasa dilakukan oleh umat muslim sebagai wadah atau sarana untuk mempelajari dan mendalami agama Islam. Seperti yang penulis paparkan sebelumnya, pengajian merupakan salah satu lembaga pendidikan non formal. Semua kegiatan yang ada di dalam pengajian merupakan salah satu cara untuk memberikan pendidikan keagamaan kepada jemaah di luar sekolah.

Masjid sebagai tempat pelaksanaan pengajian merupakan salah satu unsur penting dalam struktur masyarakat Islam. Masjid adalah rumah tempat ibadah umat muslim. Masjid artinya tempat sujud, dan masjid berukuran kecil juga disebut mushala atau surau. Selain tempat ibadah, masjid juga merupakan pusat kehidupan komunitas muslim. Kegiatan-kegiatan perayaan hari besar, diskusi, kajian agama, ceramah dan belajar al-Quran sering dilaksanakan di Masjid. Bahkan dalam sejarah Islam, masjid turut memegang peranan penting dalam aktivitas sosial kemasyarakatan hingga kemiliteran ${ }^{3}$.

Aktivitas sosial keagamaan yang diadakan di masjid, membuat masjid terlihat makmur olehnya, namun jika suatu kegiatan kajian agama (pengajian) dilaksanakan secara bergilir di rumah warga fungsi masjid sebagai pusat kegiatan umat akan terlihat kurang makmur. Beberapa pengajian yang dilaksanakan oleh masyarakat Desa Kedungwinangun adalah pengajian Lapanan yang dilaksanakan dengan cara tiga puluh lima hari sekali di musola dan masjid bergiliran. Pengajian Lpanan bergilir ini sudah menjadi tradisi yang terstruktur dengan fungsi-fungsinya pada masyarakat di

\footnotetext{
${ }^{3}$ Puji Astari, Mengembalikan Fungsi Masjid, hlm. 35.
} 
Jurnal Ar-Rihlah Inovasi Pengembangan Pendidikan Islam

Volume. 5. No.1. 2020 Fakultas Tarbiyah IAINU Kebumen

ISSN: $2541-402 X$

ISSN: 2851-0197

http://ejournal.iainu-kebumen.ac.id/index.php/Ar-rihlah/index

Desan Kedungwinangun. Kajian agama yang lain juga sering dilaksanakan di rumah warganya.

Melihat fenomena unik yang terjadi di Desa Kedungwinagun penulis meneliti fenomena tersebut menggunakan teori struktural fungsional milik Talcott Parsons. Teori struktural fungsional menekankan pada persyaratan fungsional yang dibutuhkan oleh masyarakat sebagai sebuah sistem untuk terus bertahan, kecenderungan masyarakat menciptakan konsensus (kesepakatan) antar anggotanya dan kontribusi peran dan stastus yang dimainkan individu/institusi dalam keberlangsungan sebuah masyarakat. Masyarakat dilihat sebagai sebuah sistem dimana seluruh struktur sosialnya terintegrasi menjadi satu, masing- masing memiliki fungsi yang berbedabeda tapi saling berkaitan dan menciptakan konsensus dan keteraturan sosial serta keseluruhan elemen akan saling beradaptasi baik terhadap perubahan internal dan eksternal dari masyarakat ${ }^{4}$.

Teori struktural fungsional mengkaji peran atau fungsi dari suatu struktur sosial atau institusi sosial dan tipe perilaku/ tindakan sosial tertentu dalam sebuah masyarakat dan pola hubungannya dengan elemen-elemen lainnya. Selain itu, juga mengkaji status, peran dan proses kerja keseluruhan masyarakat. Menurut Talcott Parsons, keberlangsungan masyarakat sebagai sistem dan bertahan dari berbagai perubahan internal dan eksternal. Ada empat persyaratan fungsional masyarakat yang dikemukakan oleh Parsons. Persyaratan fungsional masyarakat tersebut adalah adaptasi, goal attainment, integrasi dan latency. Adaptasi ditujukan untuk memperoleh sumber daya yang memadai dari lingkungan sekitar dan mendistribusikan ke seluruh sistem. Pengajian Lapanan yang ada di Desa Kedungwinangun juga perlu melakukan adaptasi dengan masyarakatnya. Hal ini ditujukan agar masyarakat mampu menerima tradisi pengajian Tepat waktu dan bergilir. Goal attainment ditujukan untuk menformulasikan tujuan utama dari suatu sistem/masyarakat.

Pengajian lapanan Temapat wkaktu dan bergilir di Desa Keudngwinangun

\footnotetext{
${ }^{4}$ George Ritzer dan Gouglas J. Goodman, Teori Sosiologi Modern, Jakarta: Prenada Media Group, 2007, hlm 118 .
} 
Jurnal Ar-Rihlah Inovasi Pengembangan Pendidikan Islam

Volume. 5. No.1. 2020 Fakultas Tarbiyah IAINU Kebumen

ISSN: $2541-402 X$

ISSN: 2851-0197

http://ejournal.iainu-kebumen.ac.id/index.php/Ar-rihlah/index

mempunyai tujuan yang ingin dicapai untuk memberikan hasil sistem masyarakat yang baik. Integrasi dipahami sebagai upaya mengkoordinasikan, mengatur hubungan antar elemen dan sistem. Elemen-elemen yang ada di dalam pengajian Lapanan saling mengatur dan terkait antara satu elemen/sistem yang satu dengan yang lain. Latency (nilai-nilai kolektif) diantaranya pendidikan, agama dan keluarga berperan mentransfer nilai kolektif yang dibutuhkan untuk kelangsungan masyarakat, melalui proses sosialisasi, institusionalisasi dan internalisasi ${ }^{5}$. Melihat hal itu, penulis menggunakan teori struktural fungsional milik Talcott Parsons untuk membantu penulis dalam menyusun sebuah penelitian ilmiah.

\section{HASIL DAN PEMBAHASAN}

Kontruksi Dalam Ativitas Masyarakat Menbaca Dinamika Pengajian Lapanan

\section{A. Aktifitas Rutin Pengajian Lapanan di Desa Kedugwinangun}

Aktifitas pengajian lapanan di Desa Kedungwinangun terbagi menjadi dua yaitu pengajian yang bersifat rutin dan pengajian yang bersifat incidental. Pengajian yang bersifat rutin adalah pengajian selapanan atau tiga puluh lima harian yang jatuh pada hari ahad akhir bulan dan triwulan yang dilaksanakan setiap tiga bulan sekali dan menepatkannya sesuai dengan hasil kesepakatan pertemuan-pertemuan triwulan tersebut, bentuk pengajian adalah pengajian umum yang diikuti oleh anggota jama'ah pengajian lapanan dan orang lain diperbolehkan untuk mengikuti pengajian triwulan tersebut, dan yang terakhir adalah pengajian kitab dan pengajian yang bersifat incidental adalah pengajian dalam memperingati hari-hari besar Islam. ${ }^{6}$

\section{a. Pelaksanaan Pengajian}

\footnotetext{
${ }^{5}$ George Ritzer dan Gouglas J. Goodman, Teori Sosiologi Modern, hlm. 121.
}

${ }^{6}$ Wawancara dengan Kiai Saifudin Djufri Ketua Pengajian Lapanan Desa Kedungwinangun pada tanggal 4 November 2018. 
Jurnal Ar-Rihlah Inovasi Pengembangan Pendidikan Islam

Volume. 5. No.1. 2020 Fakultas Tarbiyah IAINU Kebumen

ISSN: 2541-402X

ISSN: 2851-0197

http://ejournal.iainu-kebumen.ac.id/index.php/Ar-rihlah/index

Pengajian lapanan di Desa Kedungwinangun dilaksanakan satu kali dalam tiga puluh lima hari dan satu kali dalam triwulanan dengan tempat yang bergilir. Dalam pelaksanaan tersebut sebelum pengajian dimulai dari beberapa rangkaian kegiatan pra pengajian.

Dalam pelaksanaan tersebut pada umumnya sebelum pengajian rutin dimulai ada beberapa rangkaian kegiatan sebagai awalan dari pengajian tersebut yaitu : Rebananan dijadikan sebagai hiburan islami yang seluruh personilnya adalah para jama' ah pengajian lapanan sekaligus untuk menghibur para anggota sebelum pelaksanaan pengajian dilaksanakan. ${ }^{7}$ Sholawat dilantunkan sebagai bentuk kecintaan anggota muslimat kepada Nabi Muhammad SAW sekaligus sebagai wasilah untuk mendapatkan safaatnya. pelaksanaan pengajian terlebih dahulu para anggota diajak untuk tahlil bersama dan dipimpin oleh seorang imam, dengan tujuan tahlil adalah untuk mendekatkan kepada Allah dan mengirim para ulama/masayikh dan tokohtokoh pengajian lapanan Desa Kedungwinangun yang sudah meninggal. Pengajia adalah rangkaian inti dimana seorang kyai memberikan siraman rohani kepada para jamaah pengajian lapanan dengan kurang lebih 2 jam.

Penggalangan dana adalah rangkaian akhir dari acara pengajian dan dikumpulkan pada bendahara, penggalangan dana dilakukan untuk mencukupi segala sarana-prasarana atau yang berkaitan dengan kebutuhan pengajian. $^{8}$

Guna melakukan pengajian secara baik serta dapat berhasil secara maksimal dan sampai pada tujuan, maka diperlukan adanya alat yaitu yang berupa metode. Berdasarkan wawancara dengan ketua pengajian lapanan yakni:

"Metode pengajian yangt utama dipakai oleh kyai atau ustadz dalam menyampaikan materi pengajian kepada para jama'ah adalah

\footnotetext{
${ }^{7}$ Wawancara dengan Musri'ah sebagai Jama'ah Pengajan Lapanan Desa Kedungwinangun pada tanggal 7 November 2018.

${ }^{8}$ Wawancara dengan Junaedi sebagai bendahara Pengajian Lapanan Desa Kedungwinangun pada tanggal 7 November 2018.
} 
Jurnal Ar-Rihlah Inovasi Pengembangan Pendidikan Islam

Volume. 5. No.1. 2020 Fakultas Tarbiyah IAINU Kebumen

ISSN: 2541-402X

ISSN: 2851-0197

http://ejournal.iainu-kebumen.ac.id/index.php/Ar-rihlah/index

metode ceramah, tanya jawab, metode pembiasaan, metode nasehat dan metode uswatun hasanah.",

Uraian tentang penggunaan metode pengajian adalah sebagai berikut :

\section{b. Pembinaan dan mengembangkan ilmu serta keyakinan agama}

Dunia wiyah dan ukhrawiyah secara bersamaan sesuai tuntutan ajaran agama Islam yaitu iman dan takwa yang melandasi kehidupan duniawi dalam segala bidang kegiatannya. Fungsi demikian sejalan dengan pembangunan nasional.

Pengajian lapanan merupakan unit sosial yang ada dalam masyarakat yang berperan membina dan mengembangkan ilmu agama. Upaya pendidikan non-formal dilakukan secara berkala dengan intesitas pertemuan tiga puluh lima sekali.

Upaya pendampingan secara regular ini dirasa perlu untuk terus menjaga nilai-nilai yang telah ditanamkan. Tentunya, peran pengemuka agama berperan secara pro-aktif. Peran ustad berperan sebagai pengajar, pembimbing dan penutan para warga. Proses interaksi ini senatiasa dilakukan dengan semangat menjaga dan meningkatkan akhlak para warga. Sehubungan dengan hal tersebut, hasil wawancara dengan salah satu informan yang bernama hamid, menyatakan bahwa:

"Dalam pengajian lapanan kami di damping oleh Ulama-ulama pendiri pengajian lapanan setempat, yang menisis pengajian. Akan tetapi tidak hanya itu,itu saja kadang dalam satu-dua pertemuan kita juga mengundang beberapa pembicara dari luar pengajian lapanan yang mendapat perhatian besar para warga, selain kerena sudah terkenal beliau juga berceramah dengan gaya santai dan lucu. ${ }^{10}$,

hasil wawancara dengan informan lainya yang bernama Musri'ah, menyatakan bahwa. Sependapat dengan pernyataan informan sebelumnya Hamid,

"Sering-sering ki di sini panggil penceramah dari ulama luar pendiri pengajian lapanan panggil Kayai Abdul ajis. itu rame sekali yang datang. Bahkan ibu-ibu dari kelurahan sebelah menyempatkan untuk

\footnotetext{
${ }^{9}$ Wawancara dengan Kyai Saifudin Djufri Pengajian Lapanan Desa Kedungwinangun pada tanggal 4 November 2018.

${ }^{10}$ Wawancara dengan musri'ah Angota Pengajian Lapanan Desa Kedungwinangun pada tanggal 7 November 2018
} 
Jurnal Ar-Rihlah Inovasi Pengembangan Pendidikan Islam

Volume. 5. No.1. 2020 Fakultas Tarbiyah IAINU Kebumen

ISSN: 2541-402X

ISSN: 2851-0197

http://ejournal.iainu-kebumen.ac.id/index.php/Ar-rihlah/index

hadir. Pada saat itu tema ceramah Keyai Abdul ajis dengan tema ukuah islam miayah persahabatan. Isian ceramah beliau sungguh membatin dan memberikan kesejukan pada keseluruhan warga. Selain itu metode ceramah yang santai dan terkesan lucu membuat situasi kian semarak. ${ }^{11,}$

Informan lainya yang bernama Indri, menyatakan bahwa: Sependapat dengan pernyataan dua informan sebelumnya Hasni dan musri'ah hasil wawancara dengan.

"pengajian lapanan merupakan media atau sarana bagi para warga untuk semakin meningkatkan ilmu dan keyakinanan keberagamaanya. Tentunya, runitinitas di pengajian lapanan haruslah mengarah pada hal-hal positif dalam kehidipan sehrai-hari. Kegiatan-kegiatan pengajian, mendengarkan ceramah serata sholawat, dzikir senantiasa digalang untuk meningkatkan akhlak keberimanan para anggota lapanan pada khususnya dan untuk para warga pada umumnya. Keyai muhlisin sering berpesan, penting untuk senantiasa meningakat ilmu keberagaman guna menebalkan iman kepercayaan kita pada Allah SWT. Apalagi di tengah-tengah dunian modern segalah ujian kian banyak mulai dari pola pergaulan yang semakin bebas yang kian jamak. ${ }^{12,}$

Berangkat dari kutiapan wawacara tersebut, kita dapat melihat serta Menyimpulkan bahwa keberadaan pengajian lapanan berguna dalam membina serta mengembangkan ilmu keberagamaan para anggotanya. Tentunya, hal itu tidak hanya berkontribusi pada angota pengajian lapanan saja yang tergabung, hal-hal baik juga tentu dirasakan oleh keluarga, sanak saudara serta para kerabat. Perubahan-perubahan itu tentunya memberikan perubahan pola-pola baikpada lingkungan sosial sekitar

\section{c. Sebagai Ruang Silaturahmi dan Kontak Sosial}

Masyarakat merupakan keselurahan individu-individu yang saling berintraksi sosial dalam suatu teritori dan di balut oleh spirit psikologis

\footnotetext{
${ }^{11}$ Wawancara dengan hamid sebagai pengurus Pengajian Lapanan Desa Kedungwinangun pada tanggal 9 November 2018

${ }^{12}$ Wawancara dengan Indri Angota Pengajian Lapanan Desa Kedungwinangun pada tanggal 6 November 2018
} 
Jurnal Ar-Rihlah Inovasi Pengembangan Pendidikan Islam

Volume. 5. No.1. 2020 Fakultas Tarbiyah IAINU Kebumen

ISSN: 2541-402X

ISSN: 2851-0197

http://ejournal.iainu-kebumen.ac.id/index.php/Ar-rihlah/index

akan kerbersamaan ${ }^{13}$, berhubungan secara intergral dan senatiasa membangun interaksi sosial atau kontak sosial.

Kontak sosial merupakan salah satu syarat agar terbentuknya interaksi dalam masyrakat. Inuteraksi bermakan, pertukaran kebutuhan, kepentingan, ide atau gagasan antara satu individu dan individu lainnya. Jadi secara harfiah adalah bersama-sama menyentuh.

Pengajian Lapanan merupakan ruang sosial tentunya menghadirkan berbagai ruang interaksi antara satu anggota dengan angota lain serta dengan masyarakat secara keseluruhan.

Hal ini tentu berguna bagi keberlansungan Pengajian Lapanan, sebab, pertukaran idea tau gagasan senatiasa terjadi. Selain itu dengan adanya ruang silaturahmi bersama ini tentu menikatkan serta memupuk solidaritas antar anggota. Sehubungan dengan pernyataan tersebut bu siti, beliau menyatakan bahwa:

"Pengajian Lapanan merupakan ruang sosialisai atau metode keberagamaan antara satu dengan yang lain. Ruang silaturahmi dibutuhkan agar terjadi kekompakan antara anggota sekaligus semakin meningkatkan sensifitas antara umat beragama. Sebagai umat beragama baiknya masing-masing dari kita senantiasa menjali silaturahmi satu sama lain ${ }^{14}$."

informan lainya yang bernama Nur, Sependapat dengan pernyataan informan sebelumnya bu siti, beliau menyatakan bahwa:

"Pengajian Lapanan selain ruang untuk belajar serta meningkatkan pengetahuan pembelajaran agama, juga merupakan media sosial, dalam satu artian didalamnya ada berbagai individu dengan segalah latar belakang yang berbeda-beda. Latar belakang yang berbedabeda tersebut tidak sertamerta menciptakan jarak antara kami. Muhammad SAW berpesan umat muslim haruslah mampu memanifestasikan Habluminalla dan Habluminanas (hubungan kepada Allah SWT dan Hubungan kepada sesame manusia) olehnya

${ }^{13}$ Salman darmawan” Sosiologi Desa Revoluvi Senyap dan Tarian Kompleksisitas”. innawa.Tahun, 2012,Hlm. 19

${ }^{14}$ Wawancara dengan nur Angota Pengajian Lapanan Desa Kedungwinangun pada tanggal 11 November 2018 
Jurnal Ar-Rihlah Inovasi Pengembangan Pendidikan Islam

Volume. 5. No.1. 2020 Fakultas Tarbiyah IAINU Kebumen

ISSN: 2541-402X

ISSN: 2851-0197

http://ejournal.iainu-kebumen.ac.id/index.php/Ar-rihlah/index

ruang silaturahmi bermakna penting dalam kehidupan beragama dan bermasyrakat ${ }^{15}$.

Dari hasil Riviuw wawancara diatas dapat melihat serta mengambarkan bahwa dalam Pengajian Lapanan tidak hanya menjadi medium pembelajaran ilmu-ilmu agama. Akan tetapi Nilai-nilai sosial menjadi skala prioritas dalam perjalan Pengajian Lapanan. Silaturahmi, menolong sesame, kontak sosial serta bakti sosial senantiasa digagas. Berbagai aktifitas tentu tidak terlepas dari kontribusi dari para pemuka-pemuka agama setempat. Peran pemuka agama sebagai penutan memerankan tugastugasnya baik di bidang agama atau spiritual dan sosial. Sehubungan dengan hal tersebut, salah satu informan yang di temui bernama idirs menyatakan bahwa:

"Peran pemuka agama setempat secara khusus iman mesjid berperan yang cukup signifikan dalam membentuk karakter mental para warga, secara khusus anggota Pengajian Lapanan. Kemudian ditanamkan tidaklah dalam nilai-nilai agama, nilai sosial menjadi bagian yang penting dalam pembelajaran dalam Pengajian Lapanan. Kegiatan yang berorentasi pada nilai sosial seperti bakti sosial, silaturahmi antar anggota dan warga serta pembangunan mesjid senantiasa di galang serta di usahakan. ${ }^{16,}$

\section{d. Dampak keberadaan Pengajian Lapanan terhadap perubahan kehidupan}

Keberadaan Pengajian Lapanan dalam era globalisasi sangat penting dan menjadi salah satu benteng terpenting dalam menangkal dampak negatif dari globalisasi itu sendiri. Selain itu juga berfungsi sebagai membina dan mengembangkan agam islam, taman rekreasi rohani, ajang silahturahmi, sarana dialog secara berkesinambungan antara ulama dan umat manusia serta sebagai media penyampaian gagasan dan ajaran islam yang bermanfaat bagi pembangunan umat. Pengajian Lapanan juga dapat menjadi penyuluhan agama kepada masyarakat, karena sebagai anggota Pengajian Lapanan adalah tokoh masysrskst, bapak-bapak dan ibu-ibu yang sangat dekat dengan generasi muda yang di harapkan akan mampu

\footnotetext{
${ }^{15}$ Wawancara dengan bu siti Angota Pengajian Lapanan Desa Kedungwinangun pada tanggal 7 November 2018

${ }^{16}$ Wawancara dengan musri'ah Angota Pengajian Lapanan Desa Kedungwinangun pada tanggal 6 November 2018
} 
Jurnal Ar-Rihlah Inovasi Pengembangan Pendidikan Islam

Volume. 5. No.1. 2020 Fakultas Tarbiyah IAINU Kebumen

ISSN: 2541-402X

ISSN: 2851-0197

http://ejournal.iainu-kebumen.ac.id/index.php/Ar-rihlah/index

akan mampu menjadi agen-agen perubahan dan pembinaan generasi muda sehingga lebih memiliki arah yang sesuai dengan koridor agama islam.

Pengajian Lapanan merupakan salah satu unit sosial dalam masyarakat yang kemudian memainkan peran pendidikan non-formal dalam masyarakat. Dalam perkembangannya Pengajian Lapanan menanamkan berbagai nilai-nilai agama guna sebagai petunjuk, pembimbing serta pedoman bagi umat muslim dalam kehidupan bermasyarakat. Berbagai upaya yang dilakukan guna meningkatkan kualitas akhlak umat muslim tentunya telah memberikan berbagai macam bentuk-bentuk perubahan yang mengarah pada perubahan positif. Hal itu dapat dijabarkan sebagai berikut:

\section{e. Perubahan pola pikir}

Pola pikir merupakan aspek yang kemudian mempengaruhi pola interaksi seseorang atau individu dalam masyarakat. Perkembangan pola pikir tentunya sangat di pengaruhi oleh berbagai saluran-saluran pendidikan yang di dapati oleh seseorang selaku subjek dalam masyarakat. Saluransaluran pendidikan yang tidak mengajarkan nilai-nilai kemanusiaan, kesetaraan dan asas keadilan tentunya akan menjadikan setiap aktor memperoleh pemahaman-pemahaman yang keliru. Di satu sisi, keberadaan saluran-saluran pendidikan yang mengajarkan nilai-nilai kebaikan tentunya akan menjadi input yang baik pula pada actor atau individu dalam masyrakat.

Perubahan menutut pemhaman yang lebih dalam ${ }^{17}$, pola pikir adalah salah satu hal yang paling utama yang paling penting jika ingin mengubah kehidupan menjadi lebih baik. Apa pun yang di lakukan untuk mengubah pola hidup tanpa mengubah pola pikir, mengubah bentuk pola pikir bukanlah hal yang bisa anda ubah dengan cara yang instan karena me ngubah semua hal yang telah anda percaya dan telah di jalani.

Keberadaan Pengajian Lapanan selain menjadi media masyarakat desa kedungwinangun dalam menikatkan pengetahuan keberagamaanya dan telah membentuk serta membangun pola pikir tersendiri bagi setiap anggotanya. Sehubungan dengan pernyataan bahwa

"di Pengajian Lapanan dapat mengubah pola pikir saya, yang sebelum nya saya tidak mengenal betul ajaran agama. Ceramah-

${ }^{17}$ Khadziq. "Islam dan Buday Lokal,Belajar Memahami Agama dalam Masyrakat”. Teras. Thun 2009. Hlm.79 
Jurnal Ar-Rihlah Inovasi Pengembangan Pendidikan Islam

Volume. 5. No.1. 2020 Fakultas Tarbiyah IAINU Kebumen

ISSN: 2541-402X

ISSN: 2851-0197

http://ejournal.iainu-kebumen.ac.id/index.php/Ar-rihlah/index

ceramah dan kegiatan sosial dapat mengajarkan saya untuk menjadi lebih baik dalam. Kowangid. ${ }^{18}$

Selanjudnya begitu tampak senada dengan Mustaqim yang mengatakan bahwa:

"setelah saya masuk taklim saya merasakan perubahan ini dalam bertatak rama dalam lingkungan sosial maupun di keluarga. Perubahan pola pikir yang lebih mendekatkan diri kepada Allah. Swt. ${ }^{19}$ “

Sependapat dengan dua informan sebelumnya Idris dan indri, salah satu informan lainnya yang bernama musrigah mengutarakan bahwa:

"Pengajian Lapanan cenderung bergaul dengan orang-orang yang sepaham dengan fikiran kita, sehingga dapat saling berbagi sehingga pengetahuan tentang ajaran agama islam ini dapat di perdalam. Hal ini dapat medekatkan diri kepada allah.swt yang telah memberikan hidayah yang dapat merubah hidup saya. ${ }^{20}$

Dari hasil peneliti dapat disimpulkan bahwa keberadaan Pengajian Lapanan memberikan dampak yang positif terhadap perserta pengajian lapanan setelah mendengarkanTosiah pada ulama yang mengisi rutinan pengajian lapanan, dan terjadi pada perubahan pola pikir yang dapat merubah kehidupan mereka menjadi lebih baik.

\section{f. Memupuk rasa solidaritas antar masyarakat}

Solidaritas yang ada di dalam lingkungan Pengajian Lapanan sangat tinggi. Dengan banyaknya aktivitas dan pengalaman yang pernah dilalui bersama masih memegang erat rasa kekeluargaan tersebut. Solidaritas ini tentunya tidak hanya mengarah pada kepentingan para anggota. Dalam beberapa kali kesempatan, keberadan Majlis taklim diorentasikan pada aktifitas-aktifitas yang mengarah pada, gotongroyong dan bakti sosial. Bakti sosial kemudian didefenisikan sebagai upaya atau hal-hal dilakukan untuk menolong sesama terkhusu orang-orang yang kurang mampu.

\footnotetext{
${ }^{18}$ Wawancara dengan Kowangid Angota Pengajian Lapanan Desa Kedungwinangun pada tanggal 8 November 2018

${ }^{19}$ Wawancara dengan mustaqim Angota Pengajian Lapanan Desa Kedungwinangun pada tanggal 5 November 2018

${ }^{20}$ Wawancara dengan indris Angota Pengajian Lapanan Desa Kedungwinangun pada tanggal 6 November 2018
} 
Jurnal Ar-Rihlah Inovasi Pengembangan Pendidikan Islam

Volume. 5. No.1. 2020 Fakultas Tarbiyah IAINU Kebumen

ISSN: 2541-402X

ISSN: 2851-0197

http://ejournal.iainu-kebumen.ac.id/index.php/Ar-rihlah/index

Berkaitan dengan hal tersebut salah satu informan yang bernama kayai Muhlisin menjelaskan bahwa:

"rasa solidaritas telah banyak sekali sudah di sampaikan dalam ceramah-ceramah tiap tiga puluh lima hari, jadi saya sudah terbiasa dengan kondisi yang ada di masyarakat, misalnya ada tetangga saya yang lagi kekurangan kami dari majlis taklim pasti membantu dengan bantuan dana maupun tenaga, dana yang kami kumpulkan tiap kegiatan pengajian berlangsung itu yang kami berikan. Tentunya, tidak ada ibalan yang kami harapkan dari proses tersebut. Sepenuhpenuh hal tersebut didasarkan pada keiklasan dan keinginan membatu sesam terkhusus bagi saudara-saudara kami yang kurang mampu $^{21}$

Selanjudnga informasn yang saya temui Senada dengan pernyataan informan sebelumnya, informan yang bernama kowangid , mengungkapkan yakni:

"kalau saya dimanapun ka berada kalau ada orang yang membutuhkan pertolongan pasti saya bantu, misalnya seperti tetangga saya yang lagi butuh dana untuk biaya persalinannya pasti saya bantu, karena saya pikir akan ada balasannya dari Allah SWT, seperti dalam tosiah trus karena ikatan yang ada dalam pengajian lapanan masih sangat tinggi rasa solidaritasnya. ${ }^{22}$

Solidaritas yang ada di lingkungan Pengajian Lapanan sangat kental dengan penanaman nilai-nilai agama yang benar serta beberapa aktivitasaktivitas di dalam Pengajian Lapanan yang mengharuskan kebersamaan serta solidaritas bersama.

Proses penanaman nilai-nilai solidaritas pada Pengajian Lapanan diharapkan dapat menjadi bekal atau pedoman dalam menjalani kehidupan bermasyarakat. Harapan tersebut tercermin dalam berbagai kenyataankenyataan keseharian yang dilakukannya.

Dalam masyrakat modern kecenderungan umum yang hadir manusia kian menjadi individualistik dan secara otomatis mengikis rasa solidaritas

\footnotetext{
${ }^{21}$ Wawancara dengan kayai mushlisin Pengajian Lapanan Desa Kedungwinangun pada tanggal 7 November 2018

${ }^{22}$ Wawancara dengan kowangid Angota Pengajian Lapanan Desa Kedungwinangun pada tanggal 7 November 2018
} 
Jurnal Ar-Rihlah Inovasi Pengembangan Pendidikan Islam

Volume. 5. No.1. 2020 Fakultas Tarbiyah IAINU Kebumen

ISSN: 2541-402X

ISSN: 2851-0197

http://ejournal.iainu-kebumen.ac.id/index.php/Ar-rihlah/index

dalam masyrakat. Keberadaan Pengajian Lapanan tentunya sebagai poros utama yang senantiasa menjaga semangat kolektifitas antara angota dan warga serta menjadi piranti pokok dalam memupuk sensifitas sosial kepada sesama.

\section{g. Menjalin silaturahmi dalam masyarakat}

Betapa pentingnya menjalin silaturrahmi sesama manusia untuk mengantarkan kita pada kebaikan. Banyak cara yang di lakukan untuk menyambung tali silaturahmi sesama manusia sehingga hidup menjadi lebih baik dan saling memuliahkan di mata Allah.SWT. Silaturahmi bukanlah murni adat istiadat namun iah merupakan bagian dari syariat.

Kolektifitas atau kekompakan sesama anggota Pengajian Lapanan sangat di tentukan oleh intensitas ruang silaturahmi yang di gagas. Silaturahmi menjadi bagian yang sangat penting, selain sebagai manifestasi dari interaksi sesama Anggota Pengajian Lapanan, ia juga memaikan peran sebagai aktifitas pertukan informasi.

Dengan adanya silaturahmi sesame anggota, informasi terkait dengan keadaaan satu anggota dengan anggota lainnya mudah untuk diketahui. Olehnya, kepekaan, sensifitas serta kepedulian sesama anggota kian hari kian terasa Semisal ada satu anggota Pengajian Lapanan yang sedang ditimpa masalah secara otomatis anggota-anggota lainnya pun turut serta membatu. Sehubungan dengan hal tersebut, hasil wawancara yang di lakukan peneliti dengan anggota Pengajian Lapanan yang bernama bu sodiah mengutarakan sebagai berikut:

"Menjalin silaturahmi itu tidak boleh di hilangkan karena sesama manusia harus menjalin hubungan itu, terutama sesama tetangga yang menjadi keluarga.sebagai makluk sosial silaturahmi tak boleh ditinggalkan. Penting untuk terus menjalin hubugan baik dengan yang lain. jadi, bila besok-besok ada masalah yang menipah salah satu dari kita, kita bisa saling bahu membahu menolong ${ }^{23}$ ”

Pernyataan informan sebelumnya isti keyai, salah satu informan lainnya ibu munah mengungkapkan yakni:

"Silaturahmi menjadi salah satu kunci sukses Pengajian Lapanan tetap bertahan. Komunikasi dan silaturahmi senantiasa kita

${ }^{23}$ Wawancara dengan sodiah Angota Pengajian Lapanan Desa Kedungwinangun pada tanggal 7 November 2018 
Jurnal Ar-Rihlah Inovasi Pengembangan Pendidikan Islam

Volume. 5. No.1. 2020 Fakultas Tarbiyah IAINU Kebumen

ISSN: 2541-402X

ISSN: 2851-0197

http://ejournal.iainu-kebumen.ac.id/index.php/Ar-rihlah/index

upayakan. Hal ini tentunya sangat berguna apa lagi kalau ada anggota kita yang rundung masalah. Secara spontan kita menawarkan bantuan sekedar untuk meminimalisir atau menyelesakan masalahnya. Di sisi lain dengan adanya ruang silaturahmi dalam Majlis taklim kita sesama anggota bisa saling mengkarabkan diri satu dengan iyang lain. ${ }^{24}$

Sependapat dengan dua informan sebelumnya musriah dan sodiah , salah satu informan lainnya yang bernama munah mengutarakan bahwa:

"Hubungan baik sesama manusia harus selalu di jaga. Di Pengajian Lapanan kita senatiasa mengupyakan hal tersebut. Karena kita paham tanpa manusia lain kita bukan siapa-siapa. Silaturahmi dan komunikasi menjadi alasan kenapa sampai sekarang kita bisa bertahan dan Pengajian Lapanan kita bisa tetap bejalan. Saling menolong sebagi bentuk perwujudan silaturahmi sesama anggota senantiasa kita tanamkan. Pengajran ini bukan cuma berlaku didalam dan bagi anggota Pengajian Lapanan saja. Pengajaran ini kemudian kita bagikan pada sanak keluarga, kerabat dan masyrakat sekitar. $^{25}$

\section{B. Temuan Penelitian}

\section{Muatan Nilai dalam Implementasinya Sosial Pengajian Lapanan di Desa Kedungwinangun}

Dalam penelitian ini terdapat banyak sekali muatan nilai-nilai pendidikan khususnya pendidikan agama Islam dan etika moral masyarakat. Sesuai dengan hasil npenelitian yang dilaksanakan.

Dalam Implementasinya penmgajian lapanan di Desa Kedungwinangun tersebut antara lain meliputi: mempertebal keimanan, meningkatkan ketaqwaan, kesungguhan berkerja dan beribadah, solidaritas sosial, pendidikan etika/moral sosial masyarakat dan muatan nilai gerakan pendidikan kerohanian. ${ }^{26}$ Penjelasan pesan pendidikan yang dapat diambil tersebut, akan dibahas satu persatu di bawah ini.

\footnotetext{
${ }^{24}$ Wawancara dengan sodiah Angota Pengajian Lapanan Desa Kedungwinangun pada tanggal 7 November 2018

${ }^{25}$ Wawancara dengan munah Angota Pengajian Lapanan Desa Kedungwinangun pada tanggal 7 November 2018

${ }^{26}$ Ibid.
} 
Jurnal Ar-Rihlah Inovasi Pengembangan Pendidikan Islam

Volume. 5. No.1. 2020 Fakultas Tarbiyah IAINU Kebumen

ISSN: 2541-402X

ISSN: 2851-0197

http://ejournal.iainu-kebumen.ac.id/index.php/Ar-rihlah/index

Dalam penelitian ini terdapat banyak sekali muatan nilai-nilai pendidikan khususnya pendidikan agama islam dan etika moral masyarakat. Sesuai dengan hasil penelitian yang dilaksanakan. Implementasinya dalam pengajian lapanan di Desa Kedungwinangun tersebut antara lain meliputi: mempertebal keimanan, meningkatkan ketakwaan, kesungguhan bekerja dan beribadah, solidaritas sosial, pendidikan etika/moral sosial masyarakat dan muatan nilai gerakan pendidikan kerohanian $^{27}$. Penjelasan pesan yang dapat diambil tersebut, akan dibahas satu persatu dibawah ini yaitu :

\section{a. Memperkuat/mempertebal Keimanan}

Aktifitas ini merupakan sebuah media untuk mendekatkan diri kepada Allah SWT dan media untuk menuntut ilmu agama, selain ibadah wajib juga lainnya seperti shalat, zakat, dan puasa. Aktifitas ini maupun riadoh mempunyai tujuan yang sama yaitu untuk bertaqorub Ilallah dengan kesungguhan tekad dan keikhlasan hati. Kaitan kadar kadar keimanan seseoran dalam aktifitas ini mampu menjawab sebagaian persoalan yang dihadapi manusia dalam menjalani kehidupan di dunia ini. Seringkali sebagian besar orang mengambil jalan pintas untuk mencapai tujuan hidup yang mapan tanpa mengindahkan kaidah-kaidah agama maupun tuntutan syari'at Islam.

Dalam hal ini mengurangi pemikiran instant dan pragmatis karena sebagaian ahli yang melakukan aktifitas pengajian lapan dengan sungguh-sungguh baik dalam berusaha/berikhtiar dan serta berserah diri atas segala ketentuan Allah sudah barang tentu merasa yakin dan tenang serta bersifat Qana'ah menerima bagi rizkinya) secara proposional serta selalu bersifat khusnudzon atas segala karunia Allah SWT. Dalam kitab Durorul Bahiyyah telah dijelaskan definisi iman yaitu: "iman adalah

\footnotetext{
${ }^{27}$ Zakiah darajat, Ilmu Pendidikan Islam, cet keenam, (Jakarta : Bumi Aksara, 2006), h. 21-22.
} 
Jurnal Ar-Rihlah Inovasi Pengembangan Pendidikan Islam

Volume. 5. No.1. 2020 Fakultas Tarbiyah IAINU Kebumen

ISSN: 2541-402X

ISSN: 2851-0197

http://ejournal.iainu-kebumen.ac.id/index.php/Ar-rihlah/index

menyakini dan memahami dalam hati, mengucapkan dengan lisan/perkataan serta menjalankan dengan perbuatan".

Merujuk dari kaida tersebut di atas adalah seseorang yang beriman selalu menyakini dan percaya adanya kekuasaan/kehendak Allah di dalam hati serta menjalankan apa yang menjadikan kewajiban sebagian seorang mukmin (orang yang beriman). Seseorang yang beriman di dalam hatinya tertanam keyakinan untuk tidak akan berpaling dari agama Allah (Islam) meskipun diiming-imingi kenikmatan dunia yang menggiurkan karena kebahagian yang bersifat sementara.

\section{b. Meningkatkan Ketakwaan}

Pendidikan yang kedua dalam aktifitas pengajian lapan adalah untuk meningkatkan ketakwaan kepada Allah SWT. Definisi dari takwa sendiri baik secara bahasa maupun secara istilah mempunyai pengertian masingmasing. Takwa secara bahasa artinya takut, sedangkan secara istilah adalah selalu menjalankan perintah Allah (ibadah) dan menjauhi segala larangannya (Amar Ma'ruf Nahi Mungkar).

Manusia memang harus takut hanya kepada Allah SWT. Takut disini bukan berarti menjauhkan dari Allah melainkan lari kembali kejalan Allah serta kepribadian luhur sebagai hamba yang bertakwa. Manusia hanyalah makhluk kecil di hadapanya-Nya yang tidak mempunyai daya upaya tanpa pertolongan-Nya. Para jama'ah pengajian lapanan ini diharapkan mampu meningkatkan ketakwaan setelah mengikuti jama'ah ini serta berpedoman bahwa segala rizki dan kenikmatan yang diperoleh merupakan Allah.

Usaha apapun dalam memperoleh karunia tersebut merupakan hanya sebagaian lantaran sehingga tidak mempunyai pemikiran bahwa apa yangtelah dimiliki merupakan hasil kerja keras dan jerih payahnya dengan menyampingkan bahwa hal tersebut merupakan pemberian dari Allah semata. Sifat ini harus dihindari manusia terlebih bagi orang yang telah masuk dalam jama'ah pengajian lapanan. Karena hal tersebut 
Jurnal Ar-Rihlah Inovasi Pengembangan Pendidikan Islam

Volume. 5. No.1. 2020 Fakultas Tarbiyah IAINU Kebumen

ISSN: 2541-402X

ISSN: 2851-0197

http://ejournal.iainu-kebumen.ac.id/index.php/Ar-rihlah/index

tersebut rentan sekali mendekati dengan kekufuran serta lupa dimana nasib mereka sebelumnya.

Sebagaian orang yang mengalami kesulitan hidup baik dari segi ekonomi, pendidikan, kesehatan serta usaha yang dihadapi akan selalu beribadah dengan tekun. Namun setelah kesejahteraan hidup mereka diperoleh maka akan sedikit terkikis aeaktifan dalam beribadah karena sangat sibuk dengan urusan di dunianya. Sikap ini sangat tidak diharapakan terlebih bagi jama'ah pengajian lapanan. Semakin tinggi kesejahteraan hidup yang diperoleh semakin tinggi pula efektifitas ibadah yang dijalankan baik ibadah mahdoh maupun ghoiru maghdoh.

\section{c. Kesungguhan Dalam Bekerja/Berusaha}

Barawal dari penjelasan diatas dapat ditelaah bahwa aktivitas pengajian lapanan merupakan awal dari proses seorang yang tadinya hanya tidak menjalankan suatu hal dengan tujuan tertentu. Sesuatu hal dalam pembahasan ini yaitu bekerja/ikhtiar.

Nilai-nilai pendidikan dalam aktifitas pengajian lapanan ini dimaksud agar manusia berusaha memenuhi hajat hidup yang beraneka ragam. Allah tidak akan menurunkan uang dari langit atau hujan emas yang dengan mudah dapat dinikmati oleh manusia.

"Allah tidak akan merubah nasib manusia apabila dirinya sendiri tidak berubah dengan kesungguhan dalam mencari sumber kehidupan. Perilaku hedonis maupun materialis haruslah dihindari dari diri setiap orang karena hanya akan menyiksa batin saja bilamana tidak dapat terpenuhi ${ }^{28}$."

Manusia manapun membutuhkan harta untuk memenuhi kebutuhan kehidupnya sehingga mereka berupaya untuk mendapatkannya dengan berbagai cara. Semestinya cara yang dipakai tentu harus halal sesuai ketentuan kaidah ajaran Islam yang berlaku. Hal yang harus diingat adalah semua harta yang kita miliki bukanlah milik kita sepenuhnya.

${ }^{28}$ Wawancara dengan marsiah Jama'ah .Pengajian Lapanan Desa Kedungwinangun pada tanggal 12 November 2018 
Jurnal Ar-Rihlah Inovasi Pengembangan Pendidikan Islam

Volume. 5. No.1. 2020 Fakultas Tarbiyah IAINU Kebumen

ISSN: 2541-402X

ISSN: 2851-0197

http://ejournal.iainu-kebumen.ac.id/index.php/Ar-rihlah/index

Harta yang kita miliki adalah amanah/titipan Allah yang sewaktu-waktu akan diambil. Kesadaran seperti inilah yang diharapkan kepada setiap orang.

Hal ini mempunyai arti dan tujuan untuk menghindari resiko stres apabila seorang mendapat musibah yang menyebab hilangnya harta benda yang dimiliki. Sebagaimana kita lihat semakin banyak orang yang sibuk dengan urusan dunia yang telah lalai akan kewajiban sebagai hamba Allah.

Akan tetapi apabila harta yang dimiliki telah hilang/berkurang mereka akan baru menyadari akan kekeliruan yang telah dilakukan sehingga mereka mulai mendekatkan diri kepada Allah dengan harapan diberi karunia kembali. Hal semacam ini bukanlah yang diharapakan melainkan dalam keadaan apapun baik susah maupun senang kita tetap istiqomah menjalankan tuntunan syari' at Islam dan melaksanakan ibadah secara Kaffah (menyeluruh).

\section{d. Kesungguhan Dalam Ibadah}

Sesuai dengan penjelasan sebelumnya bahwa manusia diciptakan hanya untuk beribadah kepada Allah SWT. Hal itu sesuai dengan firman Allah dalam Al-Qur' an Q.S Adz Dzaariyaat Ayat 56.

Arab hal 51

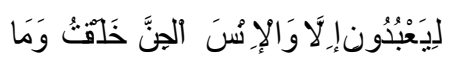

Artinya:

"Dan aku tidak menciptakan jin dan manusia kecuali untuk menyembah kepada-Ku"29.

${ }^{29}$ Abdullah bin Abdul Aziz Ali Sa’ud, Op.Cit., h. 862. 
Jurnal Ar-Rihlah Inovasi Pengembangan Pendidikan Islam

Volume. 5. No.1. 2020 Fakultas Tarbiyah IAINU Kebumen

ISSN: 2541-402X

ISSN: 2851-0197

http://ejournal.iainu-kebumen.ac.id/index.php/Ar-rihlah/index

Dalam hal ini mengajarkan tentang arti pentingnya pelaksanaan dalam beribadah harus dilaksanakan dengan sesungguh-sungguhnya Di zaman modern yang serba canggih ini sperti sekarng banyak orang yang berpendapat bahwa orang melaksanakan ibadah dengan sungguhsungguh tetapi masih banyak yang hidup dalam garis kemiskinan tetapi orang yang meninggalkan ibadah/abdah semaunya sendiri melainkan mereka yang berkehidupan yang layak. Hal ini menyebabkan pemikiran pemikiran kolot yang menyebabkan menurunnya efektivitas ibadah yang dilaksanakan. Penyakit yang semacam ini merupakan tantangan bagi umat Islam.

Tantangan berat seperti inilah yang dihadapi karena sebagaian besar jama'ah berangkat dari latar belakang yang bermacam-macam yang minimum pemahaman agamanya. Namun hal tersebut bukanlah sebagai hambatan melainkan cambuk dan bahan untuk intropeksi diri dalam menjalani kehidupan yang dilalui khususnya dalam berkehidupan ibadh.

Para jama'ah pengajian lapanan dituntun untuk mampu saling berinteraksi dengan yang lain tujuannya untuk salling mengisi dan melengkapi kekurangan masing-masing. Hal tersebut juga bertujuan untuk mempererattali persaudaraan antar jama'ah.

\section{e. Meningkatkan Solidaritas Sosial}

Manusia sesuai dengan kodratnya adalah makhluk sosial yang tidak dapat hidup sendiri tanpa bantuan orang lain. Manusia mempunyai keahlian, kelebihan dan kekurangan yang dimiliki. Sebagai penunjang kelancaran dalam berbagai aktifitas kehidupan yang dilaksanakan manusia bahkan harus salling berinteraksi untuk mendapatkan kemudahan dalam kegiatan yang dilakukan.

Melalui media interaksi dan musyawarah dapat menghasilkan sebuah kesepakatan yang disetujui bersama untuk dijalankan dengan penuh tanggung jawab. Kemajemukkan hajat hidup manusia terdiri dari 
Jurnal Ar-Rihlah Inovasi Pengembangan Pendidikan Islam

Volume. 5. No.1. 2020 Fakultas Tarbiyah IAINU Kebumen

ISSN: 2541-402X

ISSN: 2851-0197

http://ejournal.iainu-kebumen.ac.id/index.php/Ar-rihlah/index

dua macam yaitu hajat atau kepentingan dan kepentingan pribadi/sendiri ${ }^{30}$.

Kebutuhan hidup ini tentu dapat terpenuhi karena adanya interaksi dan kerja sama yang baik. Tanpa kerja sama yang baik niscaya tidak akan mendapatkan apa yang diharapakan selama ini. Nasib dan hidup seseorang tidaklah sama sebagaimana falsafah hidup layaknya roda yang berputar kadang diatas kadang dibawah. Baik orang yang bernasib mujur ataupun tidak semuanya adalah ketentuan Allah yang apabila dikaji secara mendalam merupakan ujian.

Seseorang yang hidupnya dalam kesenangan (duniawi) merupakan ujian apakah dia membelanjakan nhartanya secara benar atau tidak sesuai dengan ajaran agama seperti infak, amal jariyah, zakat, maupun sadaqah atau hanya menhambur-hamburkan hartanya dijalan yang tidak diridhoi oleh Allah seperti judi, mabuk-mabuk, narkoba, atau bermain perempuan.

Sebab dalam harta yang dimiliki ada hak bagi orang yang tidak mampu seperti fakir miskin, yatim piatu, orang jompo bahkan gelandangan dan anak jalanan yang tersebar di kota-kota besar yang hidup berada di kolong jembatan. Melalui uluran tangan bagi mereka mampulah memberikan kehidupan yang lebih baik ataupun memberi sedikit kebahagian untuk mereka, jama'ah pengajian lapanandalam hal ini tentang solidaritas sangat dianjurkan dan selalu diberikan dalam setiap kegiatan pengajian lapanan.

Mereka selalu berusaha ikhlas tentang harta yang mereka belanjakan untuk kepentingan bersama. Dalam hal ini para jama'ah pengajian lapanan pada umunya selalu berupaya menanamkan dan menerapkan rasa kesetiakawanan sosial dalam diri mereka baik dalam pelaksanaan maupun dalam kehidupan sehari-hari ${ }^{31}$. Peningkatan Moral/Etika

\footnotetext{
${ }^{30}$ Zul Kifli dkk, Pola Interaksi Sosial, cet pertama, (Jakarta : Karya Media, 2004), h. 32.

${ }^{31}$ Wawancara dengan bu siti Jama'ah Pengajian Lapanan Desa Kedungwinangun pada tanggal 12 November 2018.
} 
Jurnal Ar-Rihlah Inovasi Pengembangan Pendidikan Islam

Volume. 5. No.1. 2020 Fakultas Tarbiyah IAINU Kebumen

ISSN: 2541-402X

ISSN: 2851-0197

http://ejournal.iainu-kebumen.ac.id/index.php/Ar-rihlah/index

Masyarakat Berbicara masalah moral merupakan hal yang sangat melekat dalam kehidupan manusia. Moral merupakan cerminan dari karakter kepribadian seseorang, melalui moral yang dimiliki seorang dapat mengetahui kepribadian orang lain dan sebaliknya, moral banyak sekali sumbernya diantaranya Al-Qur'an dan Hadist, norma kesusilaan, norma adat, norma sosial, norma agama, dan norma hukum.

Bagaimana norma diatas dalam jama'ah pengajian lapanan berusaha diterapkan dalam kehidupan sehari-hari. Norma kesusilaan bersumber pada kaidah/aturan yang berlaku dalam suatu masyarakat tertentu yang merupakan norma-norma atau aturan-aturan yang telah disepakati bersama, sangsi dari norma ini mungkin saja dimarginalkan dalam masyarakat.

Norma adat bersumber dari adat istiada/kebiasan yang berlaku dalam masyarakat tertentuyang merupakan warisan dari leluhur secara turun temurun, pelanggran sangsi norma adat dapat berupa tidak diakuinya status keturunan dalam marga/golongan tertentu atau dapat pula pengucilan dari adat istiadat.

Norma agama bersumber dari aturan-aturan atau ajaran agama yang mengikuti bagi setiap pemeluknya. Sangsi pelanggaran ini selain menanggung dosa juga dapat cemoohan dari masyarakat sulit diterima dalam kegiatan keagamaan. Norma hukum bersumber dari undangundang, sangsi norma ini dipertanggung jawabkan dihadapan hukum ${ }^{32}$. Penjelasan dari norma-norma diatas menjadi pedoman agar lebih hati-hati dan selalu intropeksi dari dalam menjalani kehidupan baik secara individu maupun banyak masyarakat) yang merupakan sebuah tuntutan maupun kewajiban setiap orang.

\footnotetext{
${ }^{32}$ Wawancara dengan Kyai Saifudin Djufri Ketua Lapanan Desa Kedungwinangun pada tanggal 5 November 2018.
} 
Jurnal Ar-Rihlah Inovasi Pengembangan Pendidikan Islam

Volume. 5. No.1. 2020 Fakultas Tarbiyah IAINU Kebumen

ISSN: 2541-402X

ISSN: 2851-0197

http://ejournal.iainu-kebumen.ac.id/index.php/Ar-rihlah/index

Harapan dalam pelaksanaan jama'ah pengajian lapanan mengenai pesan moral/etika masyarakat adalah bagaimana para jama'ah pengajian lapanan dapat lebih mawasdiri dalam melangkah dalam segala hal baik urusan dunia maupun urusan akhirat. Jama'ah pengajian lapanan selalu berusaha untuk menjadi mediator bagi seseorang yang mempunyai persoalan karena mungkin saja pernah dialami sesama jama'ah pengajian lapanan.

\section{a. Pengajin Lapanan Sebagai Nilai Gerakan Pendidikan Kerohanian}

Gerakan kerohanian merupakan kepercayaan kepada sang pecipta serta budaya spiritual yang berunsurkan tuntunan luhur dan wujud perilaku, hukum, ilmu suci yang dihayati dengan hati nurani dalam kesadaran dan keyakinan, dengan membina keteguhan tekad dan perilaku budi pekerti dalam tata pergaulan menuju kedewasaan rohani demi mencapai kesajehteraan hidup dunia dan akhirat.

Dengan melakukan kegiatan tersebut orang dapat membebaskan dirinya dari keadaan sekitarnya, hal ini dapat memberikan pikiran dan membuatnya mengerti dan menghayati hakikat hidup serta selaras antara kehidupan jasmani dan kehidupan rohani.

Apabila seseorang telah bebas dari beban kehidupan duniawi maka setelah orang tersebut melalui beberapa tahapan berikutnya, pada suatu saat akan dapat menemukan ketenangan batin dan ketentraman jiwa.

\section{KESIMPULAN}

Berdasarkan kajian diatas dan keterbatasan-keterbatas ini, maka penulis dapat simpulkan beberapa hal sebagai berikut : Dalam nilai-nilai pendidikan islam dalam aktivitas jam'ah pengajian lapanan anatar lain adalah keimanan, ketaatan, beribadah/ketaqwaan, solidaritas sosial, kesuguhan dalam berkerja, etika sosial dengan keanekaragaman budaya dan gerakan pendidikan kerohanian social dalam masyarakat sebagai landasan kehidpan beragama menuju terbentuknya masyarakat sebagai landasan kehidupan beragama menuju terbentuknya masyarakat aman, tentram, adil, dan makmur. 
Jurnal Ar-Rihlah Inovasi Pengembangan Pendidikan Islam

Volume. 5. No.1. 2020 Fakultas Tarbiyah IAINU Kebumen

ISSN: $2541-402 X$

ISSN: 2851-0197

http://ejournal.iainu-kebumen.ac.id/index.php/Ar-rihlah/index

Aktivitas jama'ah pengajian lapanan terbagi menjadi dua yaitu aktivitas pengajian lapanan yang bersifat rutin dan aktivitas pengajian lapanan yang bersifat incidental. Aktivitas pengajian lapanan yang bersifat rutin adalah pengajian yang dilakukan setiap tiga pilih lima hari sekali (selapanandina) yang dilaksanakan setiap hari ahad pada akhir bulan, pengajian triwulan yang dilaksanakan setiap tiga bulan sekali dan penepatannya sesuai dengan hasil kesepakatan pertemuan-pertemuan triwulan tersebut dan pengajian kitab. Dalam pelaksanaan sebelum pengajian rutin dimulai ada beberapa rangkaian kegiatan sebagai awalan dari penajian tersebut yaitu: Rebananan, Sholawatan, Tahlil, dan pengajian rutin sebagai inti dati acara. Dan aktivitas pengajian lapanan yang bersifat incidental adalah pengajian yang dilakukan dalam memeperingati hari-hari besar Islam.

\section{Daftar Pustaka}

Abdullah bin Abdul Aziz Ali Sa'ud, 1971. Al Qur'an dan Terjemahannya. Jakarta :Yayasan Penyelenggara Penerjemahan / Penafsiran Al Qur'an.

Zakiah darajat, 2006, ,Ilmu Pendidikan Islam, cet keenam, (Jakarta : Bumi Aksara,

Khadziq. 2009."Islam dan Buday Lokal,Belajar Memahami Agama dalam Masyrakat". Teras.

Salman darmawan, 2012" Sosiologi Desa Revoluvi Senyap dan Tarian Kompleksisitas".innawa.

George Ritzer dan Gouglas J. Goodman, 2007, Teori Sosiologi Modern, Jakarta: Prenada Media Group,

George Ritzer dan Gouglas J. Goodman, Teori Sosiologi Modern,

Puji Astari, Mengembalikan Fungsi Masjid,

H.A.RTilaar, 2002, PerubahanSosial Dan Pendidikan Pengantar Pedogogik Transformatif Untuk Indonesia, ( jakarta: PT Gransindo.

Wahyuni, 2018 Agama dan Pembentukan Struktur Sosial: Pertautan Agama, Budaya, dan Tradisi Sosila, (Perpustakaan Nasional, dalam terbitan KDT, )

Karya Ini Adalah Hasil Peneltian yang di biayahi oleh kementrian agama RI ( Penelitian Pembinaan Kasistas/Pemula) 